\title{
Biogas Estimation as a Basis for the Implementation of an Intermunicipal Landfill: Michoacan, Mexico
}

\author{
Iván Vera-Romero1, José Martínez Reyes', Claudio C. Espíritu-Barragán', \\ Melitón Estrada-Jaramillo1, Agustina Ortiz-Soriano², Lenin E. Medina-Orozco ${ }^{3}$ \\ ${ }^{1}$ Trajectory of Energy Engineering, University of the Cienega of Michoacan State, Sahuayo, Mexico \\ ${ }^{2}$ Trajectory of Educational Innovation, University of the Cienega of Michoacan State, Sahuayo, Mexico \\ ${ }^{3}$ Trajectory of Food Genomics, University of the Cienega of Michoacan State, Sahuayo, Mexico \\ Email: ivanverar@gmail.com
}

Received 8 February 2014; revised 9 March 2014; accepted 1 April 2014

Copyright (C) 2014 by authors and Scientific Research Publishing Inc.

This work is licensed under the Creative Commons Attribution International License (CC BY). http://creativecommons.org/licenses/by/4.0/

c) (i) Open Access

\section{Abstract}

Municipal solid waste (MSW) generated in the municipalities of Sahuayo, Jiquilpan and Venustiano Carranza in Michoacan, is deposited in open dumps becoming hot spots for health and the environment. The total population in the three municipalities is 130,497 habitants, with a per capita waste production estimated in $0.718 \mathrm{~kg} \cdot \mathrm{hab}^{-1} \cdot \mathrm{day}^{-1}\left(34,203 \mathrm{t} \cdot \mathrm{yr}^{-1}\right)$. The aim of this study was to estimate the formation of biogas for power generation from the decomposition of waste. The model used was the mexican model of biogas (version 2.0), assuming a useful life of 21 years of the landfill at a cost of 0.19 USD per $\mathrm{kWh}$, the average CFE rate for municipal public lighting. Four possible scenarios were evaluated: one optimal recovering $68 \%$ of the biogas $(10,095$ tonnes of methane in 20 years), having a savings concept in electricity of 8,015,252 USD; in the second case (optimistic intermediate), it is assumed that it obtains $61 \%$ of biogas (9046 tonnes of methane) with benefits in power generation for 7,159,679 USD; the third case (pessimistic intermediate) estimating $48 \%$ of biogas recovered, being captured 7118 tonnes of methane with profits of $5,633,846$ USD into electrical energy, the latter case (pessimistic), assuming $40 \%$ of biogas recovered, transforming 4672 tonnes of methane resultant in an economic benefit of 3,697,324 USD for electricity generation. The results justify the investment of the landfill and it is a measure to mitigate climate change and disease prevention.

\section{Keywords}

Municipal Street Lighting, Alternative Energy, Public Health 


\section{Introduction}

Mexico is among the main countries producing methane derived from landfills [1] [2] and is on top 10 countries of MSW generation [3]. The deposit of municipal solid waste in Jiquilpan, Sahuayo and Venustiano Carranza, in the state of Michoacan, Mexico (Figure 1), is performed in open dumps (Table 1), causing adverse effects on the environment [4] [5], landscape and human health [6]-[8]. The gases inhalation, contact with waste, leachate infiltration into the bodies of deepwater and contact with pathogens are vectors that can affect the human health; causing simple nausea, irritation of eyes and contact with highly carcinogenic compounds [9] [10].

An alternative solution is the implementation of an intermunicipal landfill, where the biogas generated by the decomposition of organic matter in the MSW is captured [6] [11]. This paper presents four alternative scenarios in which the landfill could generate biogas and be transformed into energy with economic benefits generated for each scenario [12]-[14].

The main reactions that are generated on a garbage dump are the anaerobic type, except for the layers in contact with air, therefore, the main reactions are: fermentative bacterial hydrolysis followed from acetogenesisacidogenesis and to finally form methane (methanogenesis), having a final composition in the gas mixture of $50 \%$ methane, $45 \%$ carbon dioxide, and $<5 \%$ of other gases [15].

Biogas (methane) generated in a landfill is potentially usable as a source of renewable energy, capturing and converting it into energy or heat. Reducing the amount of methane into the atmosphere mitigates global warming, reducing climate change. Converting methane to carbon dioxide equivalent [16], methane has a global warming potential 21 times greater than $\mathrm{CO}_{2}$ [6] [17]. The Mexican biogas model version 2.0 was used in order to simulate biogas generation. The objective of this work is to provide projections of generation and recovery more accurate and conservative of biogas according to the conditions of the country, to serve to the landfill owners and operators in Mexico as a tool for evaluating the feasibility and potential benefits of capturing and using biogas generated [18] [19].

\section{Materials and Methods}

In order to model the four scenarios was necessary change some characteristics between them. Besides estimating the generation and recovery of biogas, the model provides an estimate of methane $\left(\mathrm{CH}_{4}\right)$ and equivalent emissions of carbon dioxide $\left(\mathrm{CO}_{2}\right)$, taking the density of $\mathrm{CH}_{4}$ as $0.0007168 \mathrm{t} \cdot \mathrm{m}^{-3}$ [18] and with a predefined concentration of waste (Table 2).

Biogas production was estimated with the mexican biogas model version 2.0, developed by SCS Engineers under agreement with LMOP program (Landfill Methane Outreach) of the Environmental Protection Agency of the United States (U.S. EPA). The model generates projections of production and recovery of biogas for different scenarios depending on the management of the landfill and serves as a tool to landfill owners and operators in Mexico to evaluate the feasibility, performance and potential benefits of capturing and using biogas generated as an energy source.

To calculate the MSW generation in the municipalities (Jiquilpan, Sahuayo and Venustiano Carranza) the database of the National Institute of Statistics and Geography was used [20]. To obtain the amount of waste that is generated in the municipalities considered in this work, the value of per capita generation in the state of

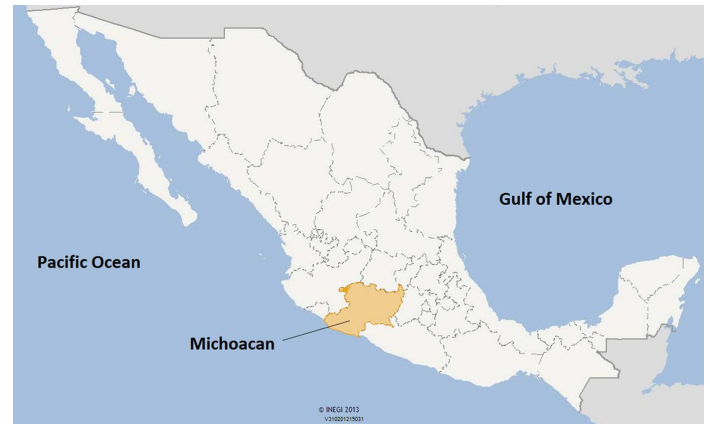

(a)

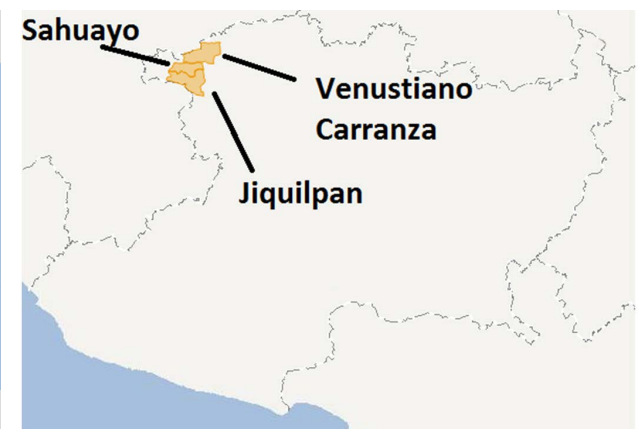

(b)

Figure 1. (a) Mexican Republic, (b) Municipalities of Michoacan (www.inegi.org.mx). 
Table 1. Population in the three municipalities.

\begin{tabular}{ccc}
\hline Municipalities & Population & Waste Generated $^{*}$ \\
\cline { 2 - 3 } & habitants & $\mathrm{t}^{-1}$ \\
Sahuayo & 72,841 & 19,091 \\
Jiquilpan & 34,199 & 8963 \\
Venustiano Carranza & 23,457 & 6148 \\
TOTAL & 130,497 & 34,203 \\
\hline
\end{tabular}

*No official information on waste recycling, incineration, composting or inert landfill.

Table 2. Characterization of municipal solid waste.

\begin{tabular}{cc}
\hline Category of waste & Site specific data \\
Food & $\%$ \\
\hline Paper and Cardboard & $34.5 \%$ \\
Pruning (gardens) & $8.1 \%$ \\
Wood & $10.6 \%$ \\
Rubber, Skin, Bones and Straw & $4.6 \%$ \\
Textiles & $2.3 \%$ \\
Other Organic & $2.3 \%$ \\
Metals & $10.5 \%$ \\
\hline
\end{tabular}

Michoacan was determined by Equation (1),

$$
I G H=\frac{\left(\frac{G R A}{D A}\right)}{H M}
$$

where $I G H$ is the value of per capita waste generation in the Michoacan State, GRA is the annual state waste generation (2008) given in kg, DA days of the year, HM is the number of inhabitants of the Michoacan State.

The value obtained $\left(0.718 \mathrm{~kg} \cdot \mathrm{hab}^{-1}\right)$ was applied to the number of residents of the three municipalities resulting an overall product of $34202.827 \mathrm{t}$ of waste per year.

The Mexican biogas model uses the equation of first order decay, expressed in Equation (2):

$$
Q_{L F G}=\sum_{t=0}^{n} \sum_{j=0.1}^{1} 2 k L_{0}\left[\frac{M_{i}}{10}\right]\left(e^{-k t_{i j}}\right)(M C F)(F)
$$

where $Q_{L F G}$ is the maximum expected biogas flow, $i$ is the annual increment, $n$ is the year of the calculation less the year of waste initial disposal, $j$ is the time increment at 0.1 years old, $M_{i}$ is the mass of waste disposed in the year $i, t_{i j}$ is the age of the section $j$ of the mass $M_{i}$ arranged in year $i, M C F$ is the methane correction factor, value dependent on the depth and type of landfill, $F$ is the adjustment factor for fire. The model assumes a value of 0.5 because the biogas consists of $50 \%$ methane and $50 \% \mathrm{CO}_{2}$ with less than $1 \%$ of other species, $k$ is the rate of generation of methane and its value depends on the moisture content, nutrient availability, $\mathrm{pH}$ and temperature in the landfill, $L_{0}$ is the methane generation potential, the $L_{0}$ and $k$ values depend on the climate zone where the site is located and speed of degradation of the waste [18].

To perform modeling four possible scenarios were established, variations are shown in Table 3.

Other considerations used in the model of biogas are: landfill receives waste for 11 years [21], Having a growth in $2 \%$ per year, landfill is a type fill trench with a depth of $12 \mathrm{~m}$ with a biogas capture system covering $85 \%$ of the area used for waste disposal. 
To calculate the amount of electricity that can be generated, Equation (3) was used, based on the results concerning the capacity of the power plant that the model provides (MW) and assuming that operates $90 \%$ of the time, also that the total biogas recovered is burned.

$$
E O=C P I \times D A \times H R \times P O \times 1000
$$

where $E O$ is the energy obtained given in $\mathrm{kWh}$; $C P I$ is the ability of the plant to install, $D A$ are the days of the year, $H R$ the hours of day and $P O$ is the percentage of operation of generation plant.

To estimate savings that would be obtained for electric power generation, it was considered an average rate 5-A from low to medium voltage of CFE (www.cfe.gob.mx), yielding a value of 0.19 USD per every kWh substituted.

\section{Results and Discussion}

The simulated period of recovery of biogas is 20 years ranging from 2013 to 2032 with benefits in different areas: environmentally, to reduce emissions of greenhouse gases released directly into the atmosphere, and the resources produced using biogas captured at the landfill to generate electricity and/or exchange of carbon emissions certificates. In Figure 2, the results of the four cases of study are shown.

Each $\mathrm{CO}_{2}$ eq tonnes reduced can be exchanged as a emission reduction certificate (CER's), with a price of 4 euros (5.62 USD), depending on the exchange rate (www.tfsgreen.com), meaning additional benefits to the production of electrical energy generated using the total of $\mathrm{CH}_{4}$ recovered at the landfill. Both resultant benefits are presented in Figure 3.

The overall 20-year results are presented in tabular form in Table 4.

At the end of landfill would be deposited 376,231 t of waste, in Table 5 are shown unit profit per ton of garbage, corresponding only to the use of biogas in electricity generation excluding CER's.

Unit costs are an indicator for detecting the feasibility of such studies. A study carried out in Malaysian involves three important aspects to determine the cost: cost of investment, operation and maintenance and, closure; with a unit total cost of 8.89 USD $^{-1}$ [22]. According to the results obtained in this study, only the first three

Table 3. Features of the proposed scenarios.

\begin{tabular}{|c|c|c|c|c|c|c|c|}
\hline \multirow{2}{*}{ Scenarios } & \multirow{2}{*}{$\begin{array}{l}\text { Management } \\
\text { Site }\end{array}$} & \multirow{2}{*}{ Fire } & \multirow{2}{*}{$\begin{array}{l}\text { Control on the } \\
\text { cover of waste }\end{array}$} & \multirow{2}{*}{$\begin{array}{c}\text { Adequate } \\
\text { compaction }\end{array}$} & \multirow{2}{*}{$\begin{array}{c}\text { Adequate } \\
\text { disposal of waste }\end{array}$} & \multicolumn{2}{|c|}{ Leachate outcrop } \\
\hline & & & & & & Rainy season & Any Season of year \\
\hline Optimistic & Yes & No & Yes & Yes & Yes & No & No \\
\hline Intermediate Optimistic & Yes & No & Yes & Yes & Yes & Yes & No \\
\hline Intermediate Pesimistic & Yes & No & Yes & Yes & Yes & Yes & Yes \\
\hline Pesimistic & No & Yes & No & No & No & Yes & Yes \\
\hline
\end{tabular}

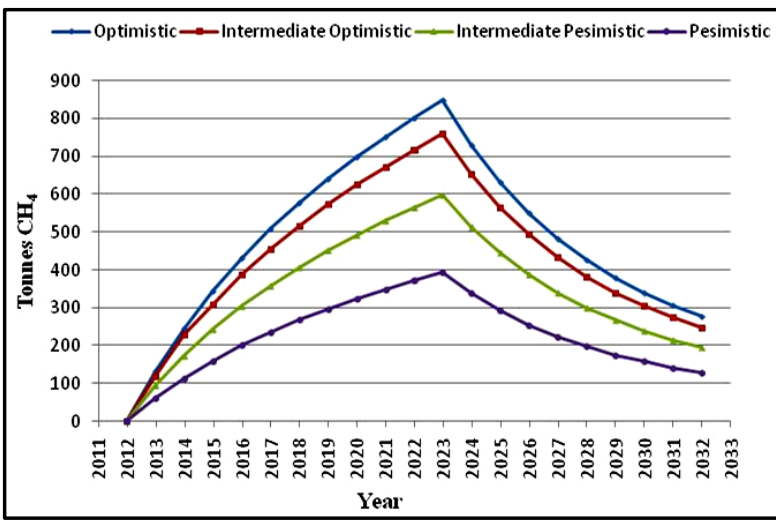

(a)

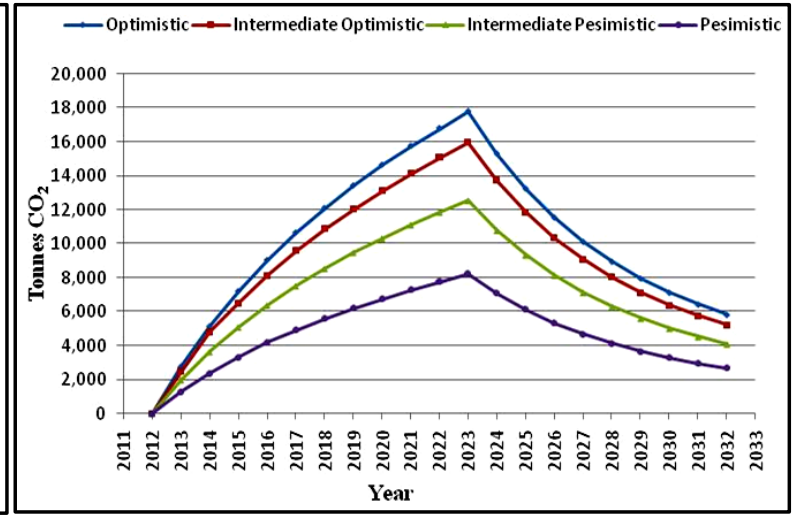

(b)

Figure 2. Reduction of emissions of $\mathrm{CH}_{4}$ annually (a) and the equivalent in $\mathrm{CO}_{2}$ (b). 


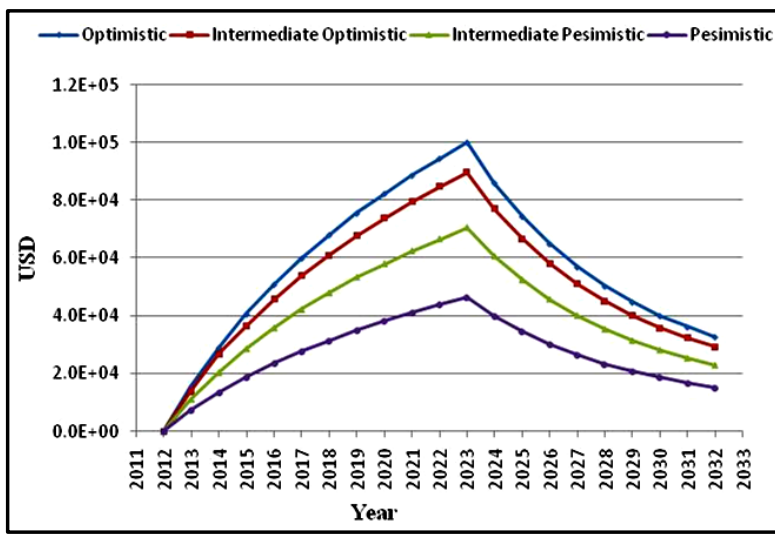

(a)

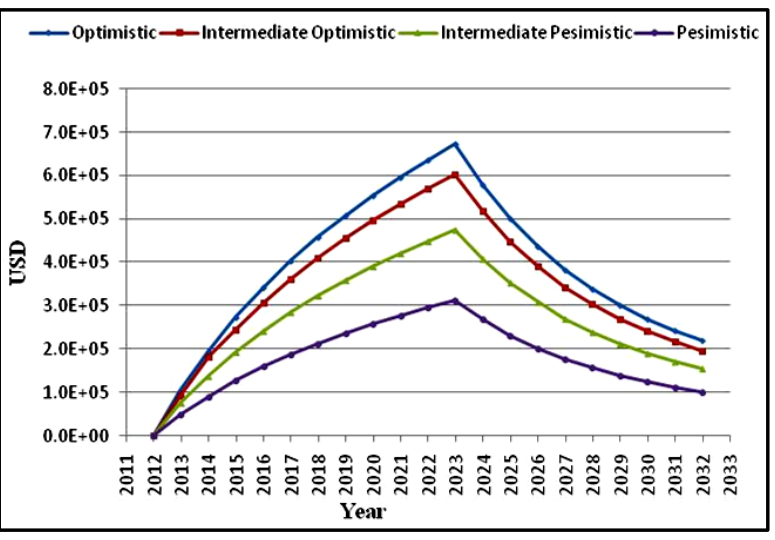

(b)

Figure 3. Gains on exchange of CER's (a) and power generation (b).

Table 4. Landfill total benefits.

\begin{tabular}{cccccc}
\hline Scenarios & $\begin{array}{c}\text { Emission Reduction } \\
\text { of } \mathrm{CO}_{2} \text { eq }(\mathrm{t})\end{array}$ & $\begin{array}{c}\text { Emission Reduction } \\
\text { of } \mathrm{CH}_{4}(\mathrm{t})\end{array}$ & $\begin{array}{c}\text { Benefit carbon } \\
\text { certificates (USD) }\end{array}$ & $\begin{array}{c}\text { Earnings per } \\
\text { energy (USD) }\end{array}$ & $\begin{array}{c}\text { Total Revenue } \\
\text { (USD) }\end{array}$ \\
\hline Optimistic & 211,999 & 10,095 & $1,190,607$ & $8,015,252$ & $9,205,860$ \\
Intermediate Optimistic & 189,969 & 9046 & $1,066,882$ & $7,159,679$ & $8,226,561$ \\
Intermediate Pesimistic & 149,484 & 7118 & 839,514 & $5,633,846$ & $6,473,360$ \\
Pesimistic & 98,102 & 4672 & 550,948 & $3,697,324$ & $4,248,272$ \\
\hline
\end{tabular}

Table 5. Benefit per ton of waste.

\begin{tabular}{cc}
\hline Scenarios & Energy savings $\left(\right.$ USD $\left.\cdot \mathrm{t}^{-1}\right)$ \\
\hline Optimistic & 19.26 \\
Intermediate Optimistic & 17.20 \\
Intermediate Pesimistic & 13.54 \\
Pesimistic & 8.88 \\
\hline
\end{tabular}

cases are acceptable. The results observed were calculated with economic values at the time the study was conducted, however, it is important to note that the economic projections are subject to change depending on the trends in the price of carbon, combustibles for electrical energy production and costs of electricity. Despite the benefits seen to implement a project of this nature, it is necessary to supplement with a technical-economic financial analysis for a complete study. And the timely characterization of waste in landfills of the municipalities involved, among others.

\section{Conclusion}

The use of biogas model provides information necessary to make an analysis of situations that could arise during the lifetime of a project of this nature, it can be displayed which are the most important components in the selection of design features or the operation of the disposal site. According to the results obtained in the simulation, just the first three cases are viable for possible implementation in the municipalities of Jiquilpan, Sahuayo and Venustiano Carranza. Moreover, the amount of recoverable methane and transformed in energy represents a significant amount ( $>339 \mathrm{t} \mathrm{CH}_{4} \mathrm{yr}^{-1}$ ), in the worst case, so it is an alternative for mitigating climate change. 


\section{References}

[1] U.S. EPA (2005) Global Anthropogenic Non- $\mathrm{CO}_{2}$ Greenhouse Gas Emissions: 1990-2020. U.S. EPA, Washington DC.

[2] Johari, A., Ahmed, S.I., Hashim, H., Alkali, H. and Ramli, M. (2012) Economic and Environmental Benefits of Landfill Gas from Municipal Solid Waste in Malaysia. Renewable and Sustainable Energy Reviews, 16, 2907-2912. http://dx.doi.org/10.1016/j.rser.2012.02.005

[3] Rawat, M. and Ramanathan, A.L. (2011) Assessment of Methane Flux from Municipal Solid Waste (MSW) Landfill Areas of Delhi, India. Journal of Environmental Protection, 2, 399-407.

[4] Kumar, S., Gaikwad, S.A., Shekdar, A.V., Kshirsagar, P.S. and Singh, R.N. (2004) Estimation Method for National Methane Emission from Solid Waste Landfill. Atmospheric Environment, 38, 3481-3487. http://dx.doi.org/10.1016/j.atmosenv.2004.02.057

[5] Laurila, T., Tuovinen, J.-P, Lohila, A., Hatakka, J., Aurela, M., Thum, T., Pihlatie, M., Rinne, J. and Vesala, T. (2005) Measuring Methane Emissions from a Landfill Using a Cost-Effective Micrometeorological Method. Geophysical Research Letters, 32. http://dx.doi.org/10.1029/2005GL023462

[6] Aguilar-Virgen, Q., Armijo-de Vega, C. and Taboada-González, P. (2009) El potencial energético de los residuos sólidos municipales. Ingeniería Revista Académica, 13, 59-62.

[7] Ayomoh, M.K.O., Oke, S.A., Adedji, W.O. and Charles-Owaba, O.E. (2008) An Approach to Tackling the Environmental and Health Impacts of Municipal Solid Waste Disposal in Developing Countries. Journal of Environmental Management, 88, 108-114. http://dx.doi.org/10.1016/j.jenvman.2007.01.040

[8] Moy, P., Krishnan, N., Ulloa, P., Cohen, S. and Brandtl-Raul, P.W. (2008) Options for Management of Municipal Solid Waste in New York City: A Preliminary Comparison of Health Risks and Policy Implications. Journal of Environmental Management, 87, 73-79. http://dx.doi.org/10.1016/j.jenvman.2007.01.032

[9] Gillett, J.W. (1992) Issues in Risk Assessment of Compost from Municipal Solid Waste: Occupational Health and Safety, Public Health, and Environmental Concerns. Biogas and Bioenergy, 3, 145-162. http://dx.doi.org/10.1016/0961-9534(92)90023-J

[10] Karak, T., Bhattacharyya, P. and Das, T. (2013) Non-Segregated Municipal Solid Waste in an Open Dumping Ground: A Potential Contaminant in Relation to Environmental Health. International Journal of Environmental Science and Technology, 10, 503-518. http://dx.doi.org/10.1007/s13762-013-0184-5

[11] Jaramillo, J. (1991) Guia para el diseño, construcción y operación de rellenos sanitarios manuales. Washington DC.

[12] Bove, R. and Lunghi, P. (2006) Electric Power Generation from Landfill Gas Using Traditional and Innovative Technologies. Energy Conversion and Management, 47, 1391-1401. http://dx.doi.org/10.1016/j.enconman.2005.08.017

[13] Murphy, J.D. and McKeogh, E. (2004) Technical, Economic and Environmental Analysis of Energy Production from Municipal Solid Waste. Renewable Energy, 29, 1043-1057. http://dx.doi.org/10.1016/j.renene.2003.12.002

[14] Murphy, J.D., McKeogh, E. and Kiely, G. (2004) Technical/Economic/Environmental Analysis of Biogas Utilisation. Applied Energy, 77, 407-427. http://dx.doi.org/10.1016/j.apenergy.2003.07.005

[15] Temelis, N. J. and Ulloa, P.A. (2007) Methane Generation in Landfills. Renewable Energy, 32, 1243-1257. http://dx.doi.org/10.1016/j.renene.2006.04.020

[16] Camargo, Y. and Vélez, A. (2009) Emisiones de biogás producidas en rellenos sanitarios. II Simposio Iberoamericano de Ingeniería de Residuos, Barranquilla, 24-25.

[17] Batjes, N.H. and Bridges, E.M. (1992) World Inventory of Soil Emissions. International Soil Reference and Information Centre, 11-35. http://www.isric.org/isric/webdocs/docs/ISRIC_Report_1992_04.pdf

[18] Stege, G.A. and Davila, J.L. (2009) Manual del Usuario Modelo Mexicano de Biogás Versión 2.0. Washington DC.

[19] Aguilar-Virgen, Q., Armijo-de Vega, C. and Taboada-González, P. (2011) Modelo mexicano para la estimación de la generación de biogás. Ingeniería Revista Académica, 15, 37-45.

[20] INEGI, México en cifras. (2012). http://www3.inegi.org.mx/sistemas/mexicocifras/default.aspx?e=16

[21] Flores, R., Muñoz-Ledo, R., Flores, B.B. and Cano, K.I. (2008) Estimación de la generación de energía a partir de biomasa para proyectos del programa de mecanismo de desarrollo limpio. Revista Mexicana de Ingeniería Química, 7, 35-39.

[22] Chong, T.L., Matsufuji, Y. and Hassan, M.N. (2005) Implementation of the Semi-Aerobic Landfill System (Fukuoka Method) in Developing Countries: A Malaysia Cost Analysis. Waste Management, 25, 702-711. http://dx.doi.org/10.1016/j.wasman.2005.01.008 